\title{
GTF2A1 L wt Allele
}

National Cancer Institute

\section{Source}

National Cancer Institute. GTF2A1L wt Allele. NCI Thesaurus. Code C52507.

Human GT F2A1 L wild-type allele is located in the vicinity of 2p16.3 and is approximately $115 \mathrm{~kb}$ in length. This allele, which encodes TFIIA-alpha and beta-like factor protein, may be involved in gene transcription in germ cells. 